\title{
DIETA CZŁOWIEKA PÓŹNEGO ANTYKU W RELACJACH LACIŃSKICH I GRECKICH AUTORÓW CHRZEŚCIJAŃSKICH EPOKI
}

\author{
„Quando pro tuis necessitatibus procedis ad publicum, \\ das nummos, et emis tibi panem, aut vinum, aut oleum"1.
}

Literatura starochrześcijańska stanowiąc olbrzymią skarbnicę informacji, uchodzić również może za źródło poznania zwyczajów żywieniowych mieszkańców Cesarstwa Rzymskiego w IV i V wieku². Z oczywistych względów relacji dotyczących tej kwestii nie jest wiele, z reguły odnajdujemy je na marginesie innych opisów i co bardziej istotne, informacje te nie wzbogacają w jakiś szczególny sposób naszej wiedzy na temat diety człowieka późnego antyku.

Produkty spożywcze w przeważającej mierze nabywano na targu (ỏyopó/ macellum $^{3}$. Pośród najczęściej kupowanych ówcześni autorzy chrześcijańscy

${ }^{*}$ Dr hab. Ireneusz Milewski, prof. UG - profesor nadzwyczajny w Zakładzie Historii Starożytnej w Instytucie Historii na Wydziale Historycznym Uniwersytetu Gdańskiego; e-mail: hisim@univ. gda.pl.

${ }^{1}$ Augustinus, Sermo 167, 2, 3, PL 38, 910. Na temat późnoantycznych spożywczych necessaria, por. K.W. Weeber, Alltag im Alten Rom, Düsseldorf - Zürich 2000, 66-68 i 162-164.

${ }^{2}$ Poza pismami Ojców Kościoła, dla potrzeb niniejszego artykułu wykorzystane również zostały relacje z pism hagiograficznych, w których często odnajdujemy informacje na temat zwyczajów żywieniowych ówczesnych mnichów. Ich dieta ze względu na jej specyfikę oraz kontekst kulturowy to oczywiście materiał na osobne studium. Pragnę również nadmienić, iż zaprezentowana w artykule problematyka nie była w zasadzie przedmiotem moich wcześniejszych badań. Szczątkowe informacje na temat produktów spożywczych, czy też ich cen, zostały przeze mnie zebrane przy okazji kwerend przeprowadzonych dla innych celów. Na temat kwestii poruszanej w niniejszym artykule por. I. Milewski, Löhne und Preise bei den Kappadokischen Kirchenväter und bei Johannes Chrysostomus, „Münstersche Beiträge zur antiken Handelsgeschichte” 19 (2000) nr 1, 48-58; tenże, Ceny żywności w późnym Cesarstwie Rzymskim w relacjach greckich i łacińskich Ojców Kościoła, w: Historia naturalna jedzenia. Między antykiem a XIX wiekiem, red. E. Barylewska-SzymańskaB. Możejko, Gdańsk 2012, 28-31.

${ }^{3}$ Por. Gregorius Nyssenus, De deitate Filii et Spriritus Sancti, PG 46, 557B; Joannes Chrysostomus, Ad illuminandos cat. 1, 22, ed. A. Piédagnel, SCh 366, Paris 1990, 160, thum. W. Kania, w: Św. Jan Chryzostom, Katechezy chrzcielne, U źródeł katechumenatu 2, Lublin 1994, 23; Theodoretus, Historia religiosa V 4, ed. P. Canivet - A. Leroy-Molinghen SCh 234, Paris 1977, 334, thum K. Augustyniak: Teodoret z Cyru, Dzieje miłości Bożej, ŹM 7, Kraków - Tyniec 1994, 132 i 145; 
wymieniają chleb 4 . Co oczywiste, wzmiankowany on jest jako podstawowy produkt spożywczy dla szerokich rzesz mieszkańców Cesarstwa Rzymskiego. Takie twierdzenie jest zasadne, nie mniej jednak pamiętać również należy o pochodzeniu społecznym, a tym samym stopniu zamożności szerokich rzesz słuchaczy kazań (pośród których biedni stanowili przytłaczającą większość) oraz zwrócić uwagę na fakt nawiązań w literaturze starochrześcijańskiej do chleba, jako metafory ewangelicznej ${ }^{5}$. O chlebie jako podstawowym produkcie diety człowieka późnego antyku wspominają między innymi św. Ambroży z Mediolanu ${ }^{6}$ oraz Jan Kasjan ${ }^{7}$. W ich relacjach mamy raczej do czynienia $\mathrm{z}$ poślednim jego gatunkiem, chlebem jęczmiennym (panis cibarius) ${ }^{8}$. Za luksusowy towar spożywczy uchodził natomiast wówczas chleb pieczony z pszennej mąki (panis candidus, panis siligneus) ${ }^{9}$.

W interesujących nas relacjach źródłowych jako kolejny podstawowy produkt spożywczy odnajdujemy ryby ${ }^{10}$. Autorzy starochrześcijańscy, wzmianku-

Hieronymus, Epistula 52, 12, PL 22, 537, tłum. J. Czuj: Św. Hieronim, Listy, I, Warszawa 1952, 345; Ambrosius, De Elia et ieiunio VIII 24, PL 14, 705C. Zob. także Augustinus, Confessiones III 7, 13, ed. I. Volpi, NBA 1, Roma 1985, 68, thum Z. Kubiak: Św. Augustyn, Wyznania, Warszawa 1987, 54, gdzie Augustyn wspomina o praktykowaniu w jego czasach w Hipponie popołudniowej przerwy w handlu na targu; Weeber, Alltag, s. 146-148.

${ }^{4}$ Por. Palladius, Historia Lausiaca 2, ed. C. Butler: The Lausiac History of Palladius, vol. 2: The Greek Text edited with introduction and notes, Cambridge 1904, 17, w. 6-8, thum. S. Kalinkowski: Palladiusz, Opowiadania dla Lausosa (Historia Lausiaca), ŹM 12, Kraków - Tyniec 1996, 81; Hieronymus, Vita Sancti Hilarionis 5, 3-4, ed. E.M. Morales, SCh 508, Paris 2007, 228, thum. B. Degórski: Św. Hieronim, Żywoty mnichów: Pawła, Hilariona, Malchusa, ŹM 10, Kraków Tyniec 1995, 124; tamże 13, 10, SCh 508, 252, ŹM 10, 138; Gregorius Nyssenus, De deitate Filii et Spriritus Sancti, PG 46, 557B; Theodoretus, Historia religiosa II 4 i 13; III 3; V 3, SCh 234, 200, 222, 250 i 232, ŹM 7, 83, 91, 101 i 131.

${ }^{5} \mathrm{~W}$ tej kwestii por. chociażby B. Górka, Jezus a chleb. Interpretacja inicjacyjna $J 6,1-71$, Kraków 2010.

${ }^{6}$ Por. Ambrosius, De Nabuthae II 8, PL 14, 733C, thum. R. Pankiewicz w: Św. Ambroży, Wybór pism, PSP 35, Warszawa 1986, 28. W tej kwestii por. także J. Jundziłł, Pieniądz w tacińskiej literaturze chrześcijańskiej późnego Cesarstwa Rzymskiego, Warszawa 1994, 83.

${ }^{7}$ Por. Joannes Cassianus, De institutis coenobiorum IV 14, ed. J.C. Guy, SCh 109, Paris 1965 , 138; tenże, Collationes Patrum II 19, ed. E. Pichery, SCh 42, Paris 1955, 133, thum. A. Nocoń: Jan Kasjan, Rozmowy z Ojcami, t. 1: Rozmowy I-X, ŹM 28, Kraków - Tyniec 2002, 135. W tej kwestii por. także Jundziłł, Pieniądz, s. 82.

${ }^{8}$ Por. Hieronymus, Vita Sancti Hilarionis 5, 3-4, SCh 508, 228, ŹM 10, 124; tamże 13, 10 , SCh 508, 252, ŹM 10, 140; tenże, Vita Sancti Pauli 6, 1-2, ed. E.M. Morales, SCh 508, 154, tłum. B. Degórski, ŹM 10, 96; Theodoretus, Historia religiosa II 4, SCh 234, 220, ŹM 7, 83; Apophthegmata Patrum IV 13 (191), ed. J.C. Guy, SCh 387, Paris 1993, 190, thum. M. Kozera: Apoftegmaty Ojców Pustyni, t. 2: Kolekcja systematyczna, ŹM 9, Kraków - Tyniec 1995, 96; tamże VIII 4 (217), SCh 387, 400, ŹM 9, 163; tamże XIII 14 (1282), SCh 474, 240, ŹM 9, 238-239; zob. także Weeber, Alltag, s. 66-68.

${ }^{9}$ Szerzej na temat tej kwestii por. J. André, Essen und Trinken im alten Rom, Stuttgart 1998, 53 i 223, nota 149; Weeber, Alltag, s. 67.

${ }^{10}$ Por. Augustinus, Sermo 43, 6, PL 38, 257; Ambrosius, De Elia et ieiunio VIII 24, PL 14, 
jąc o rybach, podają czasami nawet ich ceny, choć wysokość owych sum jest $\mathrm{z}$ reguły nieco kłopotliwa dla badaczy gospodarki tamtego okresu ${ }^{11}$. Co oczywiste, ryby jako jeden $\mathrm{z}$ podstawowych i w miarę tanich produktów spożywczych narażony był również na spore fluktuacje cenowe, $\mathrm{z}$ tego też względu państwo czasami zmuszone było ingerować w ich wysokość, by przeciwdziałać spekulacjom na tym polu ${ }^{12}$.

W znanych mi pismach autorów starochrześcijańskich stosunkowo rzadko odnajdujemy informacje na temat spożycia mięsa ${ }^{13}$, co zapewne po części można wytłumaczyć faktem jego wysokiej ceny, a tym samym również ograniczonego kręgu jego odbiorców. Czasami jednak, na przykład przy okazji uczt weselnych, na stołach, chociażby zamożnych Antiocheńczyków, widzimy również wyszukane rodzaje ptactwa ${ }^{14}$.

Jeszcze mniej relacji, od tych dotyczących spożycia mięsa, odnajdujemy w kwestii spożycia mleka przez człowieka późnego antyku, co bez wątpienia odpowiada faktycznemu stanowi rzeczy, a nie tyle specyfice bazy źródłowej. Mleko jako produkt spożywczy jest trudny do przechowywania, szybko ulega fermentacji, tym bardziej w tamtych czasach. Zapewne więc jego spożycie przez mieszkańców miast (a to przecież realiów życia codziennego w miastach głównie dotyczą zebrane przez nas relacje źródłowe), było znikome ${ }^{15}$, co innego tereny wiejskie (co potwierdzają późnoantyczne chrześcijańskie pisma hagiograficzne), gdzie pozyskiwano i spożywano świeży produkt, albo też przetwarzano go na ser ${ }^{16}$.

Choć oliwa była również jednym z podstawowych produktów spożywczych, wzmianki na jej temat są jednak dość rzadkie w pismach późnoantycznych autorów chrześcijańskich ${ }^{17}$. Kolejny produkt powszechnego spożycia,

705C; Palladius, Historia Lausiaca 57, ed. Butler, s. 150, w. 23-24 - s. 151, w. 1, ŹM 12, 213; Apophthegmata Patrum XIII 13 (1286), SCh 474, 238, ŹM 9, 238; Joannes Chrysostomus, Adversus Judaeos or. 4, 1, PG 48, 857, tłum. J. Iluk: Jan Chryzostom, Mowy przeciwko judaizantom i Żydom. Przeciwko Żydom i Hellenom, ŹMT 41, Kraków 2007, 119.

${ }^{11}$ Por. chociażby Augustinus, De civitate Dei XXII 8, 9, PL 41, 766, thum. W. Kornatowski: Św. Augustyn, O państwie Bożym, Warszawa 1977, 570. W tej kwestii por. także Jundziłł, Pieniądz, s. 41 i 83.

${ }^{12}$ Por. Codex Theodosianus XIV 20, 1, ed. Th. Mommsen, Berolini 1905, 797.

${ }^{13}$ Por. Palladius, Historia Lausiaca 19, ed. Butler, s. 59, w. 13, ŹM 12, 125; Possydius, Vita Sancti Augustini 22, 2, PL 32, 51, thum. P. Nehring: Possydiusz z Kalamy, Żywot św. Augustyna, ŹM 26, Kraków - Tyniec 2002, 93; Apophthegmata Patrum IV 15 (199), SCh 387, 192, ŹM 9,97 (drób na biskupim stole).

${ }^{14}$ Por. Joannes Chrysostomus, Adversus Judaeos or. 4, 1, PG 48, 857, ŹMT 41, 119: „[...] ci, którzy przygotowują uroczystości weselne, gromadzą jedzenie złożone z różnorodnych potraw. Nie w dzień weselny, lecz na długo przedtem układa się z rybakami i ptasznikami, aby nie dać się zaskoczyć niedostatkiem czasu w zestawieniu spisu potraw".

${ }^{15}$ Por. André, Essen und Trinken, s. 30-131.

${ }^{16}$ Por. chociażby relacja Hieronima (Vita Malchi 5, 3, ed. E.M. Morales, SCh 508, 194, ŹM 10, 183; zob. także André, Essen und Trinken, s. 132-134.

${ }^{17}$ Por. Joannes Cassianus, De institutis coenobiorum IV 25, SCh 109, 158; Palladius, Historia 
a mianowicie warzywa i owoce, również nie są nazbyt często wymieniane w tej grupie źródeł ${ }^{18}$.

Ważną pozycją w diecie człowieka starożytności było oczywiście wino ${ }^{19}$. Ale również w tej mierze późnoantyczni autorzy chrześcijańscy dostarczają nam dość lakoniczne informacje. Można jednak w oparciu o nie wyrobić sobie opinię o gustach spożywających wino. W przeważającej większość (ze względów zapewne finansowych) pito trunki pospolite, jak można wnioskować z kontekstu przekazu najtańsze, na jakie pozwolić mógł sobie nawet człowiek biedny, w przeważającej mierze adresat homilii czy też mowy wygłaszanej przez swego pasterza ${ }^{20}$. Spożycie takiego wina miało również inne uwarunkowania, chociażby brak szerszego dostępu do świeżej wody pitnej ${ }^{21}$ wymuszał po części również picie wina bardziej rozcieńczonego, wina rzeczywiście pośledniego gatunku, które swą zawartością procentową alkoholu konserwowało świeżą wodę użytą do jego rozcieńczenia.

Co oczywiste, ze względów smakowych czy też leczniczych, wysoko ceniono wina lepszego gatunku, które - rzecz jasna - uzyskiwały również wysokie ceny. Za takowe uchodziły rodzime wina italskie, a mianowicie wino falerneńskie, albo też zaprawiane piołunem wino z Picenum, a przede wszystkim

Lausiaca 38, ed. Butler, s. 120, w. 8-10, ŹM 12, 181; tamże 57, ed. Butler, s. 150, w. 23-24 i s. 151, w. 1, ŹM 12, 213; Hieronymus, Vita Sancti Hilarionis 5, 4, SCh 508, ŹM 10, 124; Theodoretus, Historia religiosa XIV 2, SCh 257, 10, ŹM 7, 198; zob. także Jundziłł, Pieniądz, s. 82, nota 51.

${ }^{18}$ Por. Joannes Chrysostomus, Ad illuminandos cat. 1, 22, SCh 366, 160, tłum. Kania, s. 23; Hieronymus, Adversus Jovinianum II 10, PL 23, 299-300AD; tenże, Vita Sancti Hilarionis 5, 3, SCh 508, 220, ŹM 10, 124; tamże 21, 7, SCh 508, 268, ŹM 10, 154 (warzywa ogólnie); tamże 18, 4, SCh 508, 262, ŹM 10, 147 (zielony groch); tamże 17, 6, SCh 508, 260, ŹM 10, 145 (winogrona); 3, 5, SCh 508, 220, ŹM 10, 121 (figi); tamże 5, 1, SCh 508, 228, ŹM 10, 124 (soczewica); Palladius, Historia Lausiaca 18, ed. Butler, s. 48, w. 5-6, ŹM 12, 114; tamże 38, ed. Butler, s. 120, w. 8-10, ŹM 12, 180-181; tamże 57, ed. Butler, s. 150, w. 23-24 i s. 151, w. 1, ŹM 12, 213; Possydius, Vita Sancti Augustini 22, 2, PL 32, 51, ŹM 26, 93; Theodoretus, Historia religiosa II 4, SCh 234, 334, ŹM 7, 83; Apophthegmata Patrum IV 13 (191), SCh 387, 190, ŹM 9, 96; tamże X 78 (799), SCh 474, 64, ŹM 9, 199 (ogólnie warzywa i owoce); tamże IV 17 (240), SCh 387, 192, ŹM 9, 97; tamże IV 65 (1152), SCh 387, 216, ŹM 9, 107 (ogórki); tamże IV 70 (1156), SCh 387, 220, ŹM 9, 108 (śliwki).

${ }^{19}$ Por. André, Essen und Trinken, s. 140; Weeber, Alltag, s. 397.

${ }^{20} \mathrm{O}$ powszechnej dostępności taniego, pośledniej gatunku, wina donosi Ambroży z Mediolanu (De Elia et ieiunio I 12, 42, PL 14, 711D-712A), który stwierdza, iż na całodzienne jego spożywanie w tawernie mogli sobie pozwolić niezamożni mieszkańcy Imperium. Por. także Joannes Chrysostomus, Ad illuminandos cat. 5, 9, ed. A. Wenger, SCh 50bis, Paris 1970, 205, thum. W. Kania w: Św. Jan Chryzostom, Katechezy chrzcielne (homilie katechetyczne do tych, którzy mają być oświeceni oraz do neofitów, U źródeł katechumenatu 1, Lublin 1993, 78; tamże 7, 30, SCh 50bis, 244, thum. Kania, s. 107; Hieronymus, Epistula 52, 11, PL 22, 536-537, thum. Czuj I 344; Palladius, Historia Lausiaca 7, ed. Butler, s. 26, w. 4, ŹM 12, 91; tamże 19, ed. Butler, s. 59, w. 13, ŹM 12, 125; tamże 57, ed. Butler, s. 150, w. 23-24 i s. 151, w. 1, ŹM 12, 213; Possydius, Vita Sancti Augustini 22, 2, PL 32, 51, ŹM 26, 93; Apophthegmata Patrum IV 59 (1148), SCh 387, 214, ŹM 9, 105; tamże IV 71 (1157), SCh 387, 220, ŹM 9, 109; X 78 (799), SCh 474, 64, ŹM 9, 199; tamże XIII 13 (1286), SCh 474, 238, ŹM 9, 238.

${ }^{21}$ Por. Weeber, Alltag, s. 395. 
jednak wina sprowadzane z odległych prowincji, jak chociażby wino fenickie (produkowane głównie w okolicach Tyru) ${ }^{22}$, czy też palestyńskie (jak chociażby wino sprowadzane z okolic Gazy) ${ }^{23}$.

Na poźnoantycznych stołach, bynajmniej jednak nie biedaków, odnajdujemy również luksusowe artykuły spożywcze. Co jest lub też nie jest luksusowym artykułem spożywczym? Odpowiedź na to pytanie nie jest jednak ani prosta ani też jednoznaczna w odniesieniu do epoki późnego antyku, choć chyba nie tylko dla tamtego okresu. I tak na przykład daktyle, które w zachodnich prowincjach cesarstwa uchodziły za towar luksusowy, na Wschodzie były postrzegane za pożywienie pospolite, spożywane między innymi przez niedbających zbytnio o strawę cielesną mnichów ${ }^{24}$. Analogicznie przez mieszkańców wschodnich prowincji postrzegane były cenione w Italii figi karyjskie ${ }^{25}$, jak również figi pochodzące $\mathrm{z}$ innych rejonów wschodniej części rzymskiego imperium $^{26}$. W porównaniu z Zachodem, we wschodnich prowincjach cesarstwa większy był również dostęp do soli (o czym szerzej w dalszej części artykułu).

Pamiętajmy też, iż adresatami homilii i mów Ojców Kościoła byli w przeważającej mierze przedstawiciele nizin społecznych, dla których choćby i biały chleb był luksusem, a co dopiero mówić o jakimś szczególnym gatunku wina, orzechów, mięs, ryb i tym podobnych. Te czynniki, a przy tym głównie zamożność potencjalnego konsumenta, należy brać pod uwagę chcąc w oparciu o zebrany przez nas materiał źródłowy zestawić listę produktów spożywczych składających się na dietę człowieka późnego antyku.

W każdym razie w badanej przez nas grupie źródeł odnajdujemy relacje na temat produktów spożywczych na zakup których mogli sobie pozwolić tylko nieliczni mieszkańcy Imperium. Tak więc pośród drogich i trudnych do zdobycia artykułów spożywczych, a nierzadko sprowadzanych również z odległych prowincji Imperium, późnoantyczni autorzy chrześcijańscy wymieniają wspomniane już powyżej figi karyjskie, orzechy kokosowe, orzechy laskowe, pieprz, miód czy też orzeszki pistacjowe. Co oczywiste, rzadkością na stole mieszkańca Imperium Rzymskiego bywały przyprawy sprowadzane spoza granic cesarstwa ${ }^{27}$. Inaczej oczywiście było z przyprawami rodzimymi, czy

${ }^{22}$ Por. Ambrosius, De Tobia XIV 50, PL 14, 778D; zob. także Jundziłł, Pieniadz, s. 85 oraz nota 60; Weeber, Alltag, s. 399-340.

${ }^{23} \mathrm{~W}$ tej kwestii por. także W.J. Hopkins, The City Region in Roman Palestine, „Palestine Exploration Quarterly" 112 (1980) 19; S.A. Kingsley, The Economic Impact of the Palestinian Wine Trade in Late Antiquity, w: Economy and Exchange in the East Mediterranean during Late Antiquity. Proceedings of a Confrerence at Somervill College (Oxford, 29 $9^{\text {th }}$ May 1999), ed. S.A. Kingsley M. Decker, Oxford 2001, 44.

${ }^{24}$ Por. Palladius, Historia Lausiaca 36, ed. Butler, s. 107, w. 6-7, ŹM 12, 168.

${ }^{25}$ Por. Hieronymus, Vita Sancti Pauli 6, 3, SCh 508, 154-156, ŹM 10, 96.

${ }^{26}$ Por. Theodoretus, Historia religiosa XVIII 4, SCh 157, 56, ŹM 7, 218; Hieronymus, Vita Sancti Hilarionis 3, 4-5, SCh 508, 220-222, ŹM 10, 121.

${ }^{27}$ Por. Hieronymus, Epistula 52, 12, PL 22, 537, thum. Czuj I 345; Augustinus, De moribus Ecclesiae catholicae et de moribus Manichaeorum II 13 29, PL 32, 1357; tenże, Sermo 61, 2, 2, PL 
też różnego rodzaju ziołami, powszechnie stosowanymi wówczas w kuchni ${ }^{28}$. Może nie powszechny, ale dość częstym musiał być także dostęp do soli, skoro na przyprawianie nią swoich potraw stać było nawet mnichów ${ }^{29}$.

Czy w badanym materiale źródłowym odnajdujemy informacje na temat rodzaju konkretnych dań spożywanych przez człowieka późnego antyku? Stosunkowo niewiele. Hieronim w jednym ze swoich listów wspomina o powszechnym rozsmakowaniu współczesnych w soku z buraków oraz w zupach $\mathrm{z}$ roztartymi w nich warzywami ${ }^{30}$. W jednym zaś ze swych dzieł hagiograficznych dopowiada, iż polewka taka była z reguły „zaciągana” mąką ${ }^{31}$.

Zestawiony powyżej materiał źródłowy nie wzbogaca nazbyt naszej wiedzy o diecie, czy też zwyczajach żywieniowych człowieka późnego antyku. W sporej mierze jest to bowiem warunkowane analizowanym materiałem źródłowym, w którym informacje na temat interesujących nas tu kwestii pojawiają z reguły sporadycznie. Niewiele też odnajdujemy tam informacji na temat konkretnych cen produktów spożywczych, występują tam natomiast utyskiwania na ich drożyznę ${ }^{32}$, co pozwala bardziej zrozumieć sens, a w zasadzie kontekst $\mathrm{w}$ jakim autorzy starochrześcijańscy tak często nawiązują w swych pismach do konieczności wspierania bliźniego, jako wypełnienie nie tylko ewangelicznego nakazu wsparcia jałmużną bliźniego, lecz również jako praktyczny sposób ulżenia jego ciężkiej sytuacji materialnej, a mówiąc krótko niedoborom żywieniowym, które bywały wówczas również nierzadko przyczyną rewolt czy też tumultów społecznych ${ }^{33}$. Zauważmy, iż w przeanalizowanym materiale źródłowym sporadycznie pojawia się mleko jako produkt spożywczy, wspomina się natomiast o jego pochodnych, choćby o serze. Niewielkie spożycie mleka, głównie w warunkach miejskich, było zapewne dyktowane trudnościami w jego przechowywaniu, jest to bowiem produkt ulegający szyb-

38, 410; Sermo 210, 8, 10, PL 38, 1052; Joannes Chrysostomus, In Epistulam I ad Timotheum hom. 17, 3, PG 62, 594, tłum. T. Sinko: Św. Jan Złotousty, Homilie na Listy Pasterskie św. Pawła i na Listy do Filemona, Kraków 1949, 182-183; Apophthegmata Patrum IV 64 (1151), SCh 387, 216, ŹM 9, 107 (miód); zob. także Jundziłł, Pieniądz, s. 85 (w tym również rozważania Autora w przypisie 60); M. Wheeler, Rzym poza granicami cesarstwa, Warszawa 1958, 148.

${ }^{28}$ Por. Theodoretus, Historia religiosa I 2, SCh 234, 162, ŹM 7, 69; Hieronymus, Vita Sancti Hilarionis 5, 2, SCh 508, 228, ŹM 10, 124. Por. także Weeber, Alltag, s. 221, 298 i 359; André, Essen und Trinken, s. 167-172 i 191-193.

${ }^{29}$ Por. Hieronymus, Vita Sancti Hilarionis 5, 1, SCh 508, 228, ŹM 10, 124. Przykład mnicha Hilariona, działającego w Palestynie, nie jest może tu jednak najbardziej miarodajny. W Palestynie była znacznie większa dostępność do soli niż w innych prowincjach cesarstwa. Jednakże analogicznie brzmiące relacje odnajdujemy także w odniesieniu do mnichów syryjskich, którzy również swą codzienną dietę wzbogacali solą, por. Theodoretus, Historia religiosa II 4 i 13, SCh 234, 200 i 222, ŹM 7, 83 i 91 oraz mnichów egipskich, por. Apophthegmata Patrum IV 10 (126), SCh 387, 188, ŹM 9, 95; tamże IV 74 (1160), SCh 387, 222, ŹM 9, 109; tamże VIII 4 (217), SCh 387, 400, ŹM 9, 163.

${ }^{30}$ Por. Hieronymus, Epistula 52, 12, PL 22, 537, tłum. Czuj I 345.

${ }^{31}$ Por. tenże, Vita Hilarionis 5, 6, SCh 508, 228, ŹM 10, 125.

${ }^{32}$ Por. Milewski, Ceny żywności, s. 30.

${ }^{33}$ Por. H.P. Kohns, Hungersnot, RACh XVI 871. 
kiej fermentacji, szczególnie w rejonie śródziemnomorskim (skąd pochodzi większość przeanalizowanych przez nas relacji).

Epoka starożytna, choćby tylko ze względu na technikę uprawy ziemi i wkładany w to nakład pracy, nie znała okresu niskich cen żywności, a od połowy III w. obserwujemy w Imperium Rzymskim permanentny wzrost cen artykułów spożywczych ${ }^{34}$ i z oczywistych względów nie mogły tej tendencji przeciwdziałać próby, nazwijmy to, odgórnego sterowania cenami żywności, jak to próbował uczynić chociażby cesarz Dioklecjan w 301 r. po Chrystusie ${ }^{35}$. Normy prawne, na podobieństwo chociażby wspomnianego tu Edictum de pretis rerum venalium, wspierane autorytetem panującego bądź też groźbą szeregu sankcji karnych pozostawały martwą literą w starciu z prawami rządzącymi wolnym rynkiem, szczególnie w okresie niedoboru żywności, który $\mathrm{z}$ reguły jest również asumptem do windowania jej cen.

Powyższe rozważania, choć niebyt bogate w konkretne relacje źródłowe mogą jednak okazać się przydatne dla badaczy późnej starożytności, szczególnie dla tych, którzy eksploatują dla swych potrzeb skarbnicę późnoantycznej literatury chrześcijańskiej. Chodzi mianowicie o, rzec by się chciało, odwieczną już kwestię, a w zasadzie zarzut, z jakim przychodzi się borykać patrologom, a mianowicie panujące pośród sporej części historyków przekonanie o niewielkiej wartości poznawczej tego typu źródeł, relacji które nie odzwierciedlają w pełni realiów epoki, którą opisują. Po części jest to jednak uwaga zasadna, a nawet powyżej zestawione relacje dają nam obraz bardzo ubogiej, wręcz monotonnej diety człowieka późnego antyku, choć wiemy, iż taką wcale nie była. Nie trzeba tu oczywiście odwoływać się do opisów uczt $\mathrm{z}$ okresu późnej republiki czy też wczesnego cesarstwa ${ }^{36}$. Także inne relacje, a nawet zabytki kultury materialnej potwierdzają funkcjonowanie w późnej starożytności wysokiej kultury jedzenia, zjawiska, które chociażby w nauce niemieckiej określane jest terminem ,Tischkultur”, kuchni na najwyższym poziomie, co do jej formy, jakości jak i różnorodności. Niestety poprzez pryzmat powyżej zestawionych relacji można by wyrobić sobie zgoła odmienną opinię w tej mierze.

Pamiętajmy jednak, iż uzyskany przez nas obraz ubogiej w swej treści diety człowieka późnego antyku jest w sporej mierze skutkiem charakteru zestawionej bazy źródłowej, w której interesujące nas informacje pojawiają się co najwyżej okazjonalnie. Poza tym także folgowanie przez współczesnych

${ }^{34}$ Por. F. Kolb, Finanzprobleme und soziale Konflikte aus der Sicht zweier spätantiken Autoren (Scriptores Historiae Augustae und Anonymus de rebus bellicis), w: Studien zur antiken Sozialgeschichte. Festschrift Friedrich Vittinghoff, hrsg. von W. Eck - H. Galsterer - H. Wolf, Köln - Wien 1980, 497.

${ }^{35}$ Edictum de pretis rerum venalium, ed. i thum A. i P. Barańscy - P. Janiszewski: Edykt Dioklecjana o cenach towarów wystawionych na sprzedaż, Poznań 2007; zob. także A. Cameron, Późne Cesarstwo Rzymskie, thum. M. Kwiecień, Warszawa [2007], 51-52.

${ }^{36} \mathrm{~W}$ tej kwestii por. np. J. Carcopino, Życie codzienne $w$ Rzymie w okresie rozkwitu cesarstwa, thum. M. Pąkcińska, Warszawa 1966, 250-261. 
rozbudzonym apetytom, wyszukanym kulinarnym gustom nie było kwestią, która w opinii ówczesnych autorów chrześcijańskich zasługiwałaby na jakąś szczególną uwagę. Całkiem świadomie też przytoczyłem w tytule artykułu fragment jednej z mów św. Augustyna, z którego wynika, choć nie dosłownie, iż według uczonego biskupa z Hippony człowiek do podtrzymania swej ziemskiej egzystencji nie potrzebuje wcale wyszukanych produktów spożywczych, wystarczy mu chleb, oliwa oraz wino ${ }^{37}$.

Literatura patrystyczna nie należy do najłatwiejszej w interpretacji grupy źródeł. Sporo tu niedomówień, obraz zaś zapisanych w niej realiów życia codziennego jest nierzadko ułomny. Ale nawet mając na uwadze powyższe stwierdzić należy, iż pisma starochrześcijańskich pisarzy stanowią jednak cenne źródło dla badacza późnej starożytności.

\section{THE DIET OF THE PEOPLE IN LATE ANTIQUITY AS RECOUNTED BY THE LATIN AND GREEK ANCIENT CHRISTIAN WRITERS}

\section{(Summary)}

Ancient Christian literature is a source of an enormous wealth of information, including observations of the eating habits of the Roman Empire inhabitants in the fourth and fifth centuries. Due to the obvious reasons, those accounts are scarce as they are usually found on the margins of other descriptions. Moreover, the information provided does not shed much light on the dietary habits of the people in late antiquity. The accounts gathered by me have references to eating bread, vegetables, fish, meat (rarely), wine and olive oil. There are sporadic cases where the Fathers of the Church mention in their writings other products consumed by the inhabitants of the Roman Empire.

Słowa kluczowe: starożytne chrześcijaństwo, antyczni pisarze chrześcijańscy, późne Cesarstwo Rzymskie, życie codzienne w późnej starożytności.

Key words: ancient Christianity, ancient Christian writers, later Roman Empire, everyday life in late antiquity.

${ }^{37}$ Por. Augustinus, Sermo 167, 2, 3, PL 38, 910. Natomiast w odniesieniu do diety mnichów, Teodoret z Cyru (Historia religiosa II 13, SCh 234, 222, ŹM 7, 91) stwierdza, iż wystarczającym dlań codziennym pożywieniem był chleb oraz sól. 